Research Article

www.ijrap.net

\title{
DEVELOPMENT AND VALIDATION OF ION PAIR-LIQUID CHROMATOGRAPHIC METHOD FOR THE SIMULTANEOUS ESTIMATION OF INDAPAMIDE AND AMLODIPINE BESYLATE IN BULK AND MULTICOMPONENT FORMULATION \\ Kalyankar $\mathrm{TM}^{1}$, Khadkutkar PK ${ }^{1}$, Kakde $^{2} \mathrm{RB}^{2}$ \\ ${ }^{1}$ School of Pharmacy, Swami Ramanand Teerth Marathwada University, Nanded, Maharashtra, India \\ ${ }^{2}$ Department of Pharmaceutical Chemistry, Rashtrasant Tukdoji Maharaj Nagpur University, Nagpur, Maharashtra, India
}

Received on: 18/06/12 Revised on: 06/07/12 Accepted on: 19/09/12

*Corresponding author

Dr T. M. Kalyankar, Assistant Professor, School of Pharmacy, Swami Ramanand Teerth Marathwada University, Dyanteerth, Vishnupuri, Nanded, Maharashtra, India Email: dr.kalyankartm@gmail.com

DOI: 10.7897/2277-4343.03531

Published by Moksha Publishing House. Website www.mokshaph.com

All rights reserved.

\section{ABSTRACT}

The present paper report the simple, rapid, accurate and precise ion pair high performance liquid chromatographic method for the simultaneous estimation of Indapamide and Amlodipine Besylate in bulk and multicomponant formulation.

The reverse-phase liquid chromatographic analysis has been performed on a Hypersil $\mathrm{C}_{18}$ column $(250 \mathrm{~mm} \times 4.6 \mathrm{~mm}$ i.d., $5 \mu \mathrm{m}$ particle size $)$ column with mobile phase Methanol: Acetonitrile: $0.1 \mathrm{M}$ Heptane sulphonic acid sodium salt (1.5 ml triethylamine was added and $\mathrm{pH}$ adjusted to $3.5 \mathrm{with}$ Ortho phosphoric acid) in the ratio $20: 40: 40 \mathrm{v} / \mathrm{v} / \mathrm{v}$ and column temperature at $30^{\circ} \mathrm{C}$. The flow rate of the mobile phase was adjusted to $1.0 \mathrm{ml} / \mathrm{min}$ and the injection volume was $10 \mu \mathrm{l}$. Detection was performed at $237 \mathrm{~nm}$. The retention time for Indapamide and Amlodipine besylate were $4.13 \mathrm{~min}$ and $7.64 \mathrm{~min}$ respectively. The method was validated and shown to be linear for indapamide and Amlodipine Besylate in $25-150 \mu \mathrm{g} / \mathrm{ml}\left(\mathrm{r}^{2}=0.999\right)$ and $100-600 \mu \mathrm{g} / \mathrm{ml}\left(\mathrm{r}^{2}=0.999\right)$ respectively. The relative standard deviation of Indapamide and Amlodipine besylate for intra-day was 0.2930 and 0.1218 respectively, inter-day was found to be, 0.5905 and 0.2507 respectively.

KEYWORDS: Indapamide, Amlodipine Besylate, heptanes sulphonic acid sodium salt, RP-HPLC, ion pair liquid chromatography.

\section{INTRODUCTION}

Indapamide is chemically 4-chloro-N-(2-methyl-2,3dihydroindol-1-yl)-sulfamoyl-benzamide (structure a). Indapamide is diuretics, belongs to the class of Benzothiadiazines and also used as Antihypertensive Agents ${ }^{1,2}$.

Amlodipine Besylate is chemically (RS)-3-ethyl 5-methyl 2- [(2-aminoethoxy) methyl]-4-(2-chlorophenyl)-6methyl-1, 4-dihydropyridine-3, 5-dicarboxylate (Structure b). It is dihydropyridine type calcium channel blocker and widely used as Antihypertensive Agents ${ }^{1,3}$.

Upon detailed literature survey it was found that, individually and in combination these drugs have been analyzed by many methods such as spectrophotometric ${ }^{5,6}$, HPLC $^{7-9}$, HPTLC ${ }^{10}$ for indapamide and spectrophotometric $^{11,12}$ HPLC $^{13-15}$, HPTLC ${ }^{16}$, Chiral chromatography ${ }^{17}$, LC-MS ${ }^{18,19}$ for Amlodipine.

Indapamide API is official in the British Pharmacopoeia ${ }^{1}$ and U.S. Pharmacopeia ${ }^{2}$, Amlodipine Besylate is also is official in the British Pharmacopoeia ${ }^{1}$ and Indian Pharmacopoeia ${ }^{3}$. The combination of Indapamide and Amlodipine Besylate is not included in any pharmacopoeias. Thus, objective of present work describes the simple, accurate, precise, sensitive HPLC method for the determination of Indapamide and Amlodipine Besylate in combination. The method was validated as per the ICH guidelines.

\section{MATERIALS AND METHODS \\ Chemical and reagents}

Acetonitrile (HPLC grade), methanol (HPLC grade), triethylamine (HPLC grade), ortho-phosphoric acid (AR grade), Heptanes Sulphonic acid sodium salt (HPLC grade), water (HPLC grade) were procured from Rankem chemicals, Mumbai, India. Standard drug sample of Indapamide and Amlodipine besylate were procured from Macleoids Pvt. Ltd. Mumbai. Tablets are available in the ratio of 3:10 containing Indapamide S.R. (1.5 mg) and Amlodipine Besylate $(5 \mathrm{mg}$ ) from Natrilam of Serdia Pharmaceuticals Pvt. Ltd., Mumbai.

\section{Chromatographic condition}

Analysis was performed on chromatographic system consisted of Perkin Elimer, Series-200 pump (Quaternary system). Separation was carried out with Hypersil ODS $\mathrm{C}_{18},(250 \mathrm{x} 4.6 \mathrm{~mm}, 5 \mu$ particle size $)$ column at $30^{\circ} \mathrm{C}$ temperature with an isocratic mobile phase constituting Methanol: Acetonitrile: $0.1 \mathrm{M}$ Heptane Sulphonic Acid sodium salt $(1.5 \mathrm{ml}$ triethylamine was added and $\mathrm{pH}$ adjusted to 3.5 with o-phosphoric acid (20:40:40 v/v/v).

Preparation of 0.1 M Heptane Sulphonic acid sodium salt

About $2.0225 \mathrm{~g}$ of heptane sulphonic acid sodium salt were accurately weighed and transferred to $100 \mathrm{ml}$ volumetric flask and total volume was made up to $100 \mathrm{ml}$ with HPLC grade water to prepare $0.1 \mathrm{M}$ heptane sulphonic acid sodium salt solution.

\section{Preparation of Standard solution}

$10 \mathrm{mg}$ of Indapamide and $50 \mathrm{mg}$ of Amlodipine besylate were weighed accurately and transferred to $50 \mathrm{ml}$ 
volumetric flask and dissolved in $25 \mathrm{ml}$ of mobile phase and then volume was made up to the mark with mobile phase to get $200 \mu \mathrm{g} / \mathrm{ml}$ and $1000 \mu \mathrm{g} / \mathrm{ml}$ of stock solution of Indapamide and Amlodipine besylate respectively. A figure 2 and 3 represents the typical chromatogram of standard Indapamide and Amlodipine besylate respectively.

\section{Preparation of sample solution}

Twenty tablets, labeled as containing $1.5 \mathrm{mg}$ of Indapamide, and $5 \mathrm{mg}$ of Amlodipine besylate together with excipients, was accurately weighed, and finely powdered. A weight of powder equivalent to $1.5 \mathrm{mg}$ of Indapamide and $5 \mathrm{mg}$ of Amlodipine besylate was weighed accurately and transferred into $25 \mathrm{ml}$ volumetric flask and volume was made up to $25 \mathrm{ml}$ with Mobile phase. The contents were sonicated for 10 minutes and filtered through $0.45 \mu \mathrm{m}$ membrane filter paper. The final solution was prepared by appropriate dilution of this solution to get the concentration $30 \mu \mathrm{g}$ and $100 \mu \mathrm{g}$ of Indapamide and Amlodipine besylate respectively. A typical chromatogram of Indapamide and Amlodipine besylate are shown in figure 4.

Table 1: Validation parameter for Indapamide and Amlodipine besylate

\begin{tabular}{|c|c|c|}
\hline Validation Parameter & Indapamide & Amlodipine besylate \\
\hline Linearity (conc.) & $25-150 \mu \mathrm{g} / \mathrm{ml}$ & $100-600 \mu \mathrm{g} / \mathrm{ml}$ \\
\hline Accuracy (mean, n=3) & & 100.04 \\
\hline $80 \%$ & 99.99 & 99.83 \\
\hline $100 \%$ & 99.63 & 100.19 \\
\hline $120 \%$ & 100.02 & 100.05 \\
\hline Mean & 99.90 & 0.232 \\
\hline RSD & 0.277 & 0.2743 \\
\hline Precision & & 0.1218 \\
\hline Intraday $\%$ RSD & 0.2805 & 0.2507 \\
\hline Interday & 0.2930 & 0.000087 \\
\hline LOD & 0.5905 & 0.00026 \\
\hline LOQ & 0.0000319 & 7.64 \\
\hline Repeatability (n=6) & 0.0000967 & 1.579 \\
\hline Retention time (min) & & 7522.68 \\
\hline Resolution & 4.13 & 5300362 \\
\hline Asymmetry Factor & & 1.442 \\
\hline Theoretical plate & 10497.49 & 100.05 \\
\hline Peak area & 4409096 & 0.1233 \\
\hline Analysis of marketed Formulation & & \\
\hline \% Mean & 99.90 & \\
\hline RSD & 0.1832 & \\
\hline
\end{tabular}

Table 2: Robustness data for Indapamide and Amlodipine besylate

\begin{tabular}{|c|c|c|c|c|c|c|c|}
\hline \multirow{2}{*}{$\begin{array}{c}\text { Robust Condition } \\
\text { flow rate } \\
\end{array}$} & & \multicolumn{2}{|c|}{ Retention time (RT) } & \multicolumn{2}{|c|}{ Tailing factor } & \multicolumn{2}{|r|}{ \% assay } \\
\hline & & & & & & & \\
\hline $\mathrm{ml} / \mathrm{min}$ & & Indapamide & Amlodipine besylate & Indapamide & Amlodipine besylate & Indapamide & Amlodipine besylate \\
\hline 0.8 & -0.2 & 5.11 & 7.99 & 1.50 & 1.60 & 101.54 & 101.73 \\
\hline 1 & 0 & 4.01 & 6.80 & 1.44 & 1.552 & 99.99 & 100.06 \\
\hline \multirow[t]{2}{*}{1.2} & 0.2 & 3.66 & 5.30 & 1.32 & 1.421 & 99.99 & 99.86 \\
\hline & & \multicolumn{2}{|r|}{ RT } & \multicolumn{2}{|c|}{ Tailing factor } & \multicolumn{2}{|r|}{ \% assay } \\
\hline temp & & Indapamide & Amlodipine besylate & Indapamide & Amlodipine besylate & Indapamide & Amlodipine besylate \\
\hline 28 & -2 & 4.11 & 6.52 & 1.57 & 1.68 & 100.67 & 101.15 \\
\hline 30 & 0 & 4.01 & 6.80 & 1.44 & 1.55 & 99.99 & 100.04 \\
\hline \multirow[t]{2}{*}{32} & +2 & 4.03 & 6.28 & 1.54 & 1.52 & 100.10 & 99.42 \\
\hline & & \multicolumn{2}{|r|}{ RT } & \multicolumn{2}{|c|}{$\begin{array}{l}\text { Tailing factor } \\
\end{array}$} & \multicolumn{2}{|r|}{$\%$ assay } \\
\hline mobile phase ratio & & Indapamide & Amlodipine besylate & Indapamide & Amlodipine besylate & Indapamide & Amlodipine besylate \\
\hline $18: 38: 44$ & - & 5.04 & 2.44 & 1.54 & 1.53 & 99.50 & 99.74 \\
\hline $20: 40: 40$ & 0 & 4.01 & 6.72 & 1.44 & 1.55 & 100.01 & 100.05 \\
\hline \multirow[t]{2}{*}{$22: 36: 42$} & - & 3.77 & 6.80 & 1.47 & 1.57 & 100.38 & 101.58 \\
\hline & & \multicolumn{2}{|r|}{ RT } & \multicolumn{2}{|c|}{ Tailing factor } & \multicolumn{2}{|r|}{ \% assay } \\
\hline $\mathrm{pH}$ & & Indapamide & Amlodipine besylate & Indapamide & Amlodipine besylate & Indapamide & Amlodipine besylate \\
\hline 3.3 & -0.2 & 5.2 & 11.68 & 1.52 & 1.587 & 99.39 & 99.52 \\
\hline 3.5 & 0 & 4.01 & 6.80 & 1.44 & 1.552 & 99.99 & 100.03 \\
\hline 3.7 & +0.2 & 4.22 & 7.13 & 1.49 & 1.604 & 101.85 & 101.98 \\
\hline
\end{tabular}<smiles>CC1Cc2ccccc2N1NC(=O)c1ccc(Cl)c(S(N)(=O)=O)c1</smiles>

Figure 1(a): Indapamide<smiles>CCOC(=O)C1=C(COCCN)NC(C)=C(C(=O)OC)C1c1ccccc1Cl</smiles><smiles>O=S(=O)(O)c1ccccc1</smiles>

Figure 1(b): Amlodipine Besylate 


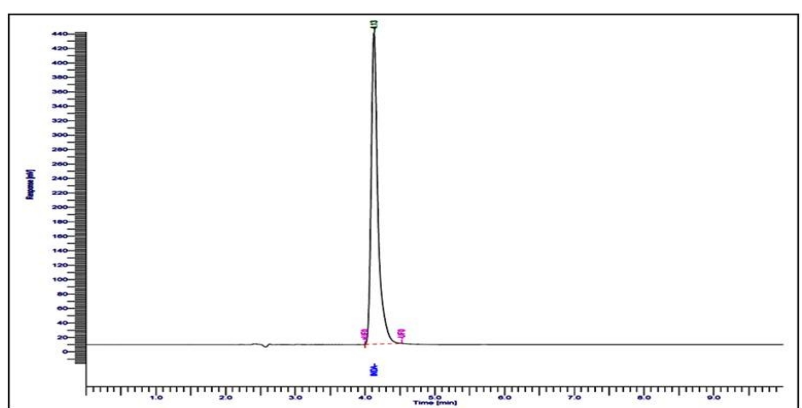

Figure 2: HPLC chromatogram of standard Indapamide

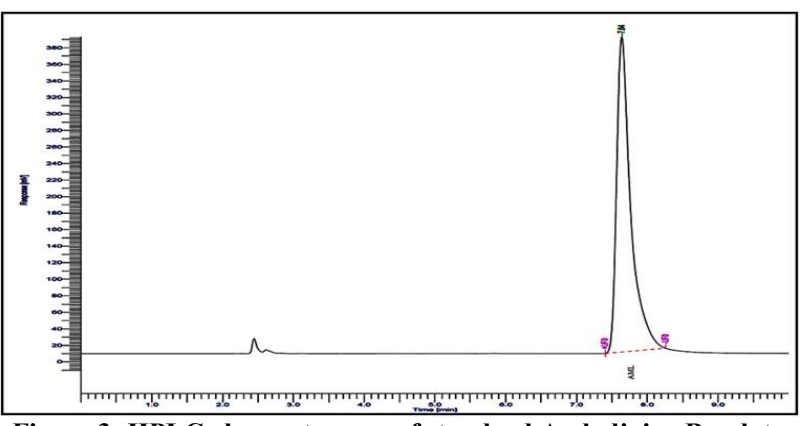

Figure 3: HPLC chromatogram of standard Amlodipine Besylate

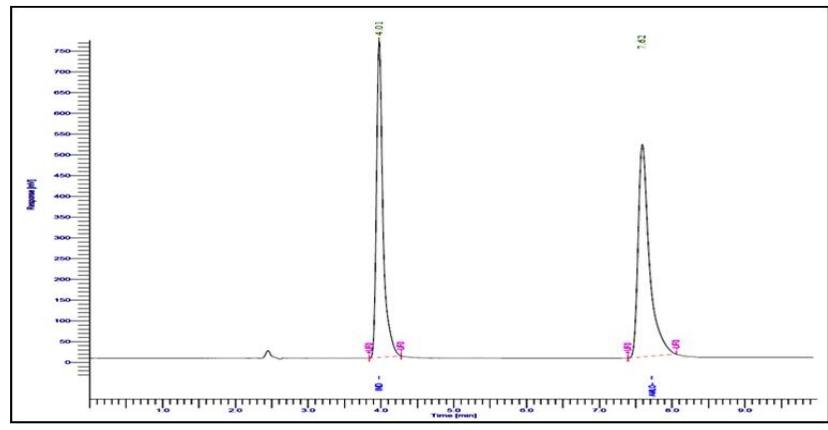

Figure 4: Typical Chromatogram of Indapamide and Amlodipine besylate mixture

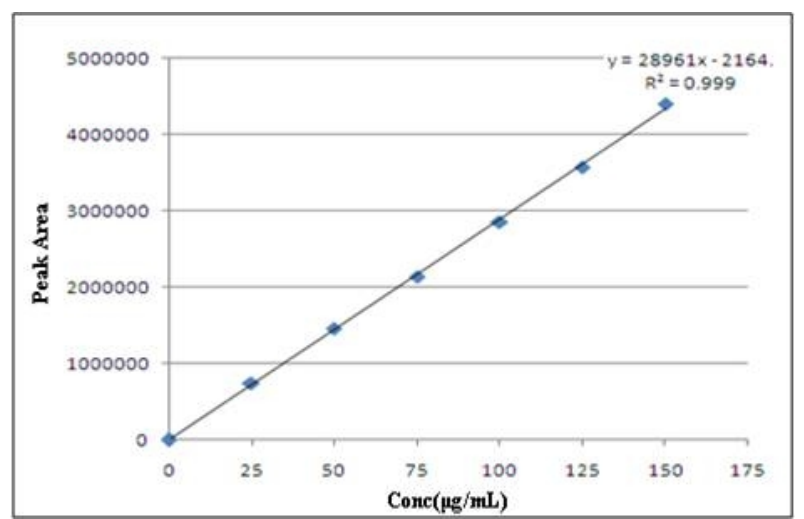

Figure 5: Calibration curve for standard Indapamide

\section{RESULTS}

\section{Calibration and Linearity}

Linearity was determined by calculating the regression line using a mathematical treatment of the results (response) versus analyte concentration. Solutions were injected in triplicate. It was determined for Indapamide in the range of $25-150 \mu \mathrm{g} / \mathrm{ml}$ (Figure 5) and 100-600 $\mu \mathrm{g} / \mathrm{ml}$ for Amlodipine besylate (Figure 6). The linear regression data for both the analyte concentration was within range i.e. $\leq 1$.

\section{Specificity and Selectivity}

The specificity of the HPLC method was determined by complete separation of Indapamide and Amlodipine Besylate by peak purity with the PDA detector. The results of the peak purity analysis show that the peaks of the analytes were pure and also the formation of excipients were not interfering with the analyte peaks.

The selectivity of an analytical method was measured accurately by the analyte of interest in the presence of components that may be expected to be present in the sample matrix. The absence of interfering endogenous

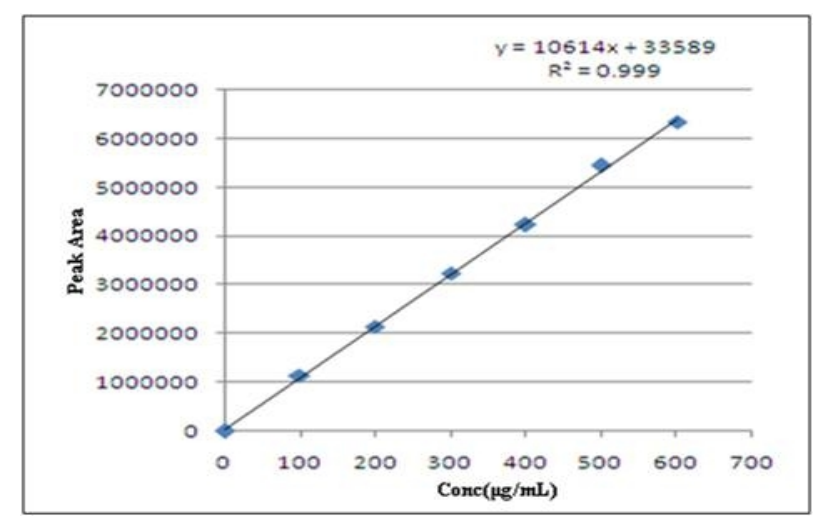

Figure 6: Calibration curve for standard Amlodipine besylate

components at the retention times of the both the drug was demonstrated by the chromatograph. The average retention time \pm standard deviation (S.D) for Indapamide and Amlodipine Besylate were found to be $4.09 \pm 0.046$ and $7.64 \pm 0.076$ respectively.

\section{Accuracy}

Accuracy was performed by recovery studies. The recovery studies were carried out at three concentration level $80 \%, 100 \%, 120 \%$ by standard addition method. The percentage recovery and standard deviation were calculated and presented in Table 1.

\section{Precision}

The precision studies were carried out as repeatability, intra-day precision and inter-day precision. The studies were performed by six replicate of the same solution using standard drug. The intra-day studies were carried at different time within same day while the inter-day precision was carried at the same time on different day. The intra- and inter-day variation (S.D. and relative standard deviation RSD) method throughout the linear range of concentrations is shown in Table 1 . 


\section{Robustness}

The robustness study was carried out by variable experimental condition as change $\mathrm{pH}$, flow rate, organic solvent ratio, and temperature. The result of robustness studies are shown in Table 2.

\section{LOD and LOQ}

The LOD and LOQ were separately determined which is based on calibration curve. The residual standard deviation of regression line or the standard deviation of $y-$ intercept of regression line may be used as standard deviation. The lower limit of Indapamide and Amlodipine besylate were found to be 0.0000319 and 0.000087 $\mu \mathrm{g} / \mathrm{mL}$ respectively. Limit of detection were found to be 0.0000967 and $0.00026 \mu \mathrm{g} / \mathrm{mL}$ for Indapamide and Amlodipine besylate respectively.

\section{System suitability}

The system suitability was checked using parameters such as tailing factor, resolution, theoretical plate number, peak area, retention time. These parameters were found to be within limit. The results of system suitability are given in Table 1.

\section{DISCUSSION}

The objective of the work was to develop the simple, accurate, precise and sensitive HPLC method for the estimation of Indapamide and Amlodipine besylate in bulk and multicomponent formulation. Both the drugs are strong basic in nature thus the efforts were made to separate these component with shorter retention time, asymmetry factor and better resolution. To achieve this goal an ion pairing agent heptane sulphonic acid sodium salt was used in mixture of mobile phase. Ion pairing agent is bind to the solute molecules by ionic interaction to increase the hydrophobicity of the solute molecule and change selectivity. Better resolution has been achieved by keeping the column temperature at $30^{\circ} \mathrm{C}$ and flow rate at $1.0 \mathrm{ml} / \mathrm{min}$. The developed method is applicable for analysis of the drug combination (Indapamide and Amlodipine besylate) in pharmaceutical formulation as this combination is not included in pharmacopoeias.

\section{CONCLUSION}

From the results obtained by all validation parameters, it is concluded that developed isocratic ion pairing RPHPLC method is suitable for the simultaneous estimation of Indapamide and Amlodipine besylate in bulk and multicomponent formulation. Therefore, the method is found to be suitable for routine analysis of marketed tablet formulations in quality control laboratories.

\section{ACKNOWLEDGEMENT}

Authors are thankful to Director of school of pharmacy, S. R. T. M., University, Nanded for their support and for providing necessary facilities to carry out this work.

\section{REFERENCES}

1. British Pharmacopoeia. Her Majesty's Stationery Office, 2009; 1-2: 149(11-5).

2. United States Pharmacopeia and National Formulary (USP 30-NF 25). Rockville, MD: United States Pharmacopoeial Convention, 2007; $2: 2340$.
3. Indian Pharmacopoeia, the Indian Pharmacopoeia Commission Ghaziabad, 2007; 2:122-123.

4. Validation of Analytical Procedures: Methodology, ICH Harmonized Tripartite Guidelines, 1996 pp 1-8.

5. Darshana KM, Chhagan NP. Development and Validation of Spectrophotometric Method for Simultaneous Estimation of Perindopril and Indapamide in Combined Dosage Form by Simultaneous Equation Method. Eurasian J Anal Chem, 2011; 6: 46- 52.

6. Pawar PV, Gaikwad PD, Bankar VH, Pawar SP. Development and validation of UV- spectrophotometric method for simultaneous estimation of Atenolol and Indapamide in bulk and tablet dosage form. Int J Pharm andTech, 2010; 2:876-885.

7. Jyoti BP, A. Sathish KS, Gopinath B, Gangaprasad C. Development and Validation of RP-HPLC Method for Quantitative estimation of Indapamide in Bulk and Pharmaceutical dosage forms, Int $\mathrm{J}$ Pharmatech. Res, 2011; 3: 1482-1487.

8. Govind JK, Vijay RR, Bhavesh LD, Hitendra SJ. HPLC method development and validation of combined dosage form of Atenolol and Indapamide in tablets. Int J Pharm and Tech, 2011; 3: 32773298.

9. Pawar PV, Gikwad PD, Bankar VH, Pawar SP, Development and validation of RP-HPLC method for Simultaneous Estimation of Atenolol and Indapamide in pharmaceutical dosage form, Int J Res Ayurveda and pharm, 2011; 2: 918-923.

10. Mohit GD, Kailash GB, Ashwini RM, Mrinalini CD. Simultaneous Estimation of perindopril erbumine and indapamide in bulk drug and tablet dosage form by HPTLC. Pharmacie Globale (IJCP) 2011; 2: $1-4$.

11. Murat O, Yucel K. Development and validation of UV spectroscopy method for determination of Amlodipine Besylate in Spiked Plasma without Derivatization. J Pharm Sci, 2007; 32: 1-6.

12. Chitlange SS, Kiran, Sakarkar DM. Stability Indicating RP- HPLC Method for Simultaneous Estimation of Valsartan and Amlodipine in Capsule Formulation. Asian J Res Chem, 2008; 1: 15-18.

13. Priyanka RP, Sachin UR, Dhabale PN, Burade KB. Simultaneous UV Spectrophotometric Method for Estimation of Losartan Potssium and Amlodipine Besylate in Tablet Dosage Form. Asian J Res Chem, 2009; 2: 183-187.

14. Snehal BP, Bharat GC, Munish KB, Ashok BP. Stability Indicating RP-HPLC method for Simultaneous determination of valsartan and Amlodipine from their combination drug product. Int J Chem Tech Res, 2009; 1: 1257-1267.

15. Jignesh P, Ajay P, Patel MB, Nimesh P, Rashmika P. Analytical method development and validation of Amlodipine besylate and Perindopril erbumine in combine dosage form by RP-HPLC. Int $\mathbf{J}$ Pharm Tech Res, 2011; 3: 801-808.

16. Anilkumar S, Bhavesh P, Rakshit P. Simultaneous estimation of nebivolol hydrochloride and S-amlodipine Besylate by High performance thin layer Chromatography. Int. J Pharm and Bio Sci, 2010; 1: 339-347.

17. Martin J, Bjorn N. Coupled-column chromatography on a ChiralAGP phase for determination of Amlodipine enantiomers in human plasma: An HPLC assay with electrochemical detection. J Pharma and Biomed Anal, 1996; 15: 267-277. http://dx.doi.org/10.1016/0731-7085(96)01836-5

18. Streel B, Laine C, Zimmer C, Sibenaler R, Ceccato A. Enantiomeric determination of Amlodipine in human plasma by liquid chromatography coupled, to tandem mass spectrometry. J Biochem Biophys $\quad$ Methods, 2002; 54: 357-368. http://dx.doi.org/10.1016/S0165-022X(02)00133-1

19. Anusak S, Kamon P, Niwan T. Determination of Amlodipine in human plasma by electrospray ionization LC-MS/MS method: validation and its stability studies. Songklanakarin J Sci Tech, 2008; 30: $455-462$.

\section{Cite this article as:}

Kalyankar TM, Khadkutkar PK, Kakde RB. Development and validation of Ion Pair-Liquid Chromatographic method for the simultaneous estimation of Indapamide and Amlodipine besylate in bulk and multicomponent formulation. Int. J. Res. Ayur. Pharm. 2012; 3(5):729732 